\title{
House dust mites atopy patch test - an important screening tool for detection of house dust mites allergy?
}

Barbara Jasiewicz-Honkisz ${ }^{1 *}$, Ida Marchewka ${ }^{2}$, Krystyna Targosz $^{3}$

From EAACI Skin Allergy Meeting 2014

Krakow, Poland. 18-20 September 2014

\section{Background}

The frequency of contact allergens is often regionally different and hence it regional identification is important for the prevention of allergic contact dermatitis (ACD).

\section{Objectives}

Aim of this study was evaluation of the frequency of particular positive results of patch test (APT).

\section{Methods}

A total number of 127 patients from Outpatient Allergic Clinic MED-ALL Medical Centre (age 2-76 years old) with suspected ACD were examined using the most common allergens from the patch tests from the European Standard Series including nickel, pallatium, chrome, cobalt, fragrance-mix I and II, balsam of Peru, formaldehyde and propolis and one extra allergen - house dust mite (HDM). The data obtained were subjected to statistical analysis.

\section{Results}

The highest positivity of APT was seen against HDM (67\%), then nickel (51\%), chrome (40\%), cobalt (39\%), pallatium (16\%), propolis (16\%), fragrance-mix I $(13,3 \%)$, balsam of Peru $(11,6 \%)$, fragrance-mix II $(9,8 \%)$ formaldehyde $(4,1 \%)$. In the group of patients with positive results with HDM higher percentage is in younger group $<18$ years old $(70 \%)$ with almost $68 \%$ of cases with strong positive results $(++$ or +++$)$.

'Department of Internal Diseases and Rural Medicine, Jagiellonian University, Cracow; Poland

Full list of author information is available at the end of the article

\section{Conclusion}

HDM allergens play an important role in determining the clinical severity of allergic dermatitis and should be included in basic patch test series.

\section{Authors' details}

'Department of Internal Diseases and Rural Medicine, Jagiellonian University, Cracow; Poland. ${ }^{2}$ Jagiellonian University, Cracow, Department of Internal Diseases and Rural Medicine, Cracow; Poland. ${ }^{3}$ Centrum Medyczne Med-ALL, Poradnia Alergologiczna, Kraków, Poland.

Published: 11 March 2015

doi:10.1186/2045-7022-5-S1-019

Cite this article as: Jasiewicz-Honkisz et al:: House dust mites atopy patch test - an important screening tool for detection of house dust mites allergy? Clinical and Translational Allergy 2015 5(Suppl 1):019.
Submit your next manuscript to BioMed Central and take full advantage of:

- Convenient online submission

- Thorough peer review

- No space constraints or color figure charges

- Immediate publication on acceptance

- Inclusion in PubMed, CAS, Scopus and Google Scholar

- Research which is freely available for redistribution

Submit your manuscript at www.biomedcentral.com/submit
() Biomed Central 